\title{
Instrumentalist Teachers' Beliefs in Practicing Mathematical Problem Solving
}

\author{
Tatag Yuli Eko Siswono ${ }^{1, *}$, Sugi Hartono ${ }^{1}$, Ahmad Wachidul Kohar ${ }^{1}$, Karim $^{2}$, Kurniawan ${ }^{3}$ \\ ${ }^{1}$ Department of Mathematics Education, Universitas Negeri Surabaya, Surabaya, Indonesia \\ ${ }^{2}$ Department of Mathematics Education, Universitas Lambung Mangkurat, Indonesia \\ ${ }^{3}$ Department of Mathematics Education, Universitas Mulawarman, Indonesia
}

Received October 10, 2019; Revised November 11, 2019; Accepted November 20, 2019

Copyright $\bigcirc 2019$ by authors, all rights reserved. Authors agree that this article remains permanently open access under the terms of the Creative Commons Attribution License 4.0 International License

\begin{abstract}
This article describes the beliefs, knowledge, and practice about mathematical problem solving of two teachers whose mathematics-related beliefs are aligned mostly with instrumentalist view, the most traditional philosophical views on mathematics-related beliefs. Data were obtained from a set of task-based interviews and lesson observation of such two teachers selected through a belief-related interview of twelve secondary mathematics teachers in Surabaya and Sidoarjo. Study findings suggest that there is consistency between the teachers' beliefs, knowledge, and their teaching practice. The consistency was seemed on their insufficient knowledge about mathematical problem solving comprising content and pedagogical knowledge, which did not support their teaching practice. Also, we found that their instrumentalist beliefs drove the ways in which they structured class discussion during their practice. Despite both the teachers espoused their beliefs in different ways regarding the extend to which associate factors such as immediate classroom situation, teacher education program, and social teaching norms influenced their beliefs, they performed similar ways in their teaching practice, which was directive particularly when guiding their students in early stages of solving mathematical problems, i.e. understanding problem and devising plan.
\end{abstract}

Keywords Instrumentalist Teacher, Problem-Solving, Teacher Beliefs, Teacher Knowledge, Teaching Practice

\section{Introduction}

Recognition of the importance of teachers' beliefs to mathematics education accelerated in the 1980s. Some of research suggests that teachers' beliefs and values about teaching and learning affect their teaching practices (Clark \& Peterson, 1986; Fang, 1996; Kagan, 1992; Thompson,
1992). The most important thing such as past school experience and immediate classroom situation, for instance, respectively, has strong influence on teachers' mathematics beliefs and teacher's teaching practice (Raymond, 1997). Beswick (2005) found significant relationships between the beliefs of mathematics teachers and the average class perceptions of their classroom environments. Specifically, teachers who created classroom environments consistent with the principles of constructivism were more likely to hold beliefs about mathematics (Beswick, 2007).

Siswono et al (2017) reported that secondary teachers' beliefs have a strong relationship with teachers' knowledge about problem solving. Teacher's knowledge, is scrutinized to have strong interaction with beliefs in shaping the teachers' teaching practice with varying degree being given to particular types of knowledge or beliefs in different situations (Bray, 2011). Bray's (2011) also argued that teacher's beliefs seemed to most likely influence on how the teacher structures class discussion, whereas teacher's knowledge appeared to push the quality of teachers' responses within classroom discussion. Moreover, Anderson et al (2005) summed up the knowledge components including mathematical content and plans, professional development, teachers' knowledge and decisions, important mathematics and assessment processes, use of math textbooks, and teacher education program.

There are several components of knowledge that teachers need in teaching, in particular on problem-solving, such as in pedagogical context (Chapman, 2015;Shulman, 1987; Wilson et al, 1987) and others revealed in the context of content (Loewenberg Ball, 2008; Ekawati, et al, 2017; Siswono, et al, 2017) . In brief, Chapman (2015) summed up the three types of knowledge for teaching problem solving: problem solving content knowledge, pedagogical problem solving knowledge, and affective factors and beliefs. (see Table 1). 
Table 1. Knowledge required in understanding problem solving

\begin{tabular}{|c|c|c|}
\hline Type of knowledge & Knowledge & Description \\
\hline \multirow{4}{*}{$\begin{array}{l}\text { Problem solving } \\
\text { content knowledge }\end{array}$} & $\begin{array}{l}\text { Mathematical problem } \\
\text { solving proficiency }\end{array}$ & Understanding what is needed for successful mathematical problem solving \\
\hline & $\begin{array}{l}\text { Mathematical } \\
\text { problems }\end{array}$ & $\begin{array}{l}\text { Understanding of the nature of meaningful problems; structure and purpose of different } \\
\text { types of problems; impact of problem characteristics on learners }\end{array}$ \\
\hline & $\begin{array}{l}\text { Mathematical problem } \\
\text { solving }\end{array}$ & $\begin{array}{l}\text { Being proficient in problem solving } \\
\text { Understanding of mathematical problem solving as a way of thinking; problem solving } \\
\text { models and the meaning and use of heuristics; how to interpret students' unusual } \\
\text { solutions; and implications of students' different approaches }\end{array}$ \\
\hline & Problem posing & Understanding of problem posing before, during and after problem solving \\
\hline \multirow{2}{*}{$\begin{array}{l}\text { Pedagogical problem } \\
\text { solving knowledge }\end{array}$} & $\begin{array}{c}\text { Students as } \\
\text { mathematical problem } \\
\text { solvers }\end{array}$ & $\begin{array}{c}\text { Understanding what a student knows, can do, and is disposed to do (e.g., students' } \\
\text { difficulties with problem solving; characteristics of good problem solvers; students' } \\
\text { problem solving thinking) }\end{array}$ \\
\hline & $\begin{array}{l}\text { Instructional practices } \\
\text { for problem solving }\end{array}$ & $\begin{array}{c}\begin{array}{c}\text { Understanding how and what it means to help students to become better problem } \\
\text { solvers }\end{array}\end{array}$ \\
\hline \multicolumn{2}{|c|}{ Affective factors and beliefs } & $\begin{array}{c}\text { Understanding nature and impact of productive and unproductive affective factors and } \\
\text { beliefs on learning and teaching problem solving and teaching }\end{array}$ \\
\hline
\end{tabular}

Regarding types of mathematics-related beliefs which might be held by teachers in teaching problem solving, several authors proposed some categories, such as Ernest (1989) with his prominent categories: instrumentalist, a Platonist, and problem solving. Our study only discusses about one category that is instrumentalist. This is because the unique characteristics of Instrumentalist view which makes it different from the other two category of philosophical beliefs, namely Platonist and problem-solving, in which many Indonesian teachers are found to have this type of beliefs regarding mathematics-related beliefs. In addition, fortified by the outcomes of the work in 2016 of 12 subject teachers there are 6 teachers who have belief instrumentalist. Furthermore, Table 2 shows several authors' view on characterized beliefs instrumentalist.

Table 2. A summary of characteristics of instrumentalist belief

\begin{tabular}{|c|c|c|}
\hline Nature of mathematics & Teaching Mathematics & Learning Mathematics \\
\hline $\begin{array}{l}\text { - Doing mathematics means finding correct } \\
\text { answers, quickly, using the (one, correct) } \\
\text { standard procedure, (Peressini et al. (2004)) } \\
\text { - Mathematics is a collection of different rules, } \\
\text { formulae and calculation methods. In the } \\
\text { learning process the goal is to achieve a } \\
\text { proficient use of them. The origin or } \\
\text { construction of rules, formulae and methods is } \\
\text { not emphasized in this approach. Grigutsch et } \\
\text { al. (1998) } \\
\text { A given body of knowledge and standard } \\
\text { procedures (Swan, 2007) } \\
\text { A set of universal truths and rules which need } \\
\text { to be conveyed to students. (Swan, 2007) }\end{array}$ & $\begin{array}{l}\text { - An instructor in the instrumentalist } \\
\text { view, (Ernest, 1989) } \\
\text { - The teaching of mathematics needs to be } \\
\text { content focused, with an emphasis on } \\
\text { performance (Beswick, 2005) } \\
\text { - Structuring a linear curriculum for the } \\
\text { students; giving verbal explanations and } \\
\text { checking that these have been } \\
\text { understood through practicing } \\
\text { questions; correcting misunderstandings } \\
\text { when students fail to 'grasp' what is } \\
\text { taught. (Swan, 2007) }\end{array}$ & $\begin{array}{l}\text { - and that learning mathematics } \\
\text { means mastering these } \\
\text { procedures" (Peressini et al. } \\
\text { (2004)) } \\
\text { - mathematical learning is seen as } \\
\text { the passive reception of } \\
\text { knowledge and the adoption of } \\
\text { different skills (Beswick, 2005) } \\
\text { - An individual activity is based } \\
\text { on watching, listening and } \\
\text { imitating until fluency is } \\
\text { attained. (Swan, 2007) }\end{array}$ \\
\hline
\end{tabular}

Many researchers have also emphasized the importance of the relationship between teachers' beliefs and their instructional practice (Ball, 1990; Cobb et al., 1990; Thompson, 1992). Based on her review of the literature, Thompson (1992) has claimed that teachers' beliefs influence classroom practice and that teachers' beliefs are evaluated and reorganized through their own reflective acts. Moreover, many scholars also have discussed on what best instructional process is which teachers ask to utilize problem solving instruction. For example, Franke, Kazemi, \& Battey (2007) explained that within problem solving instruction, instructors need to orchestrate the class discussion then that students partake in multiple problem-working out strategies, analyze the relations among strategies, and explore the contradictions in students' ideas to offer greater penetration into the mathematical focus. Besides, the four Polya's stages of solving problem, i.e. understanding problem, creating a plan, carrying away the plan, looking back, also imply how to teach problem solving (Ontario Ministry of Education, 2008). However, it is noted that those phases should be used flexibly.

Our study aims to describe the beliefs, knowledge, and practice about mathematical problem solving of two teachers whose mathematics-related beliefs are aligned mostly with instrumentalist view, the most traditional philosophical views on mathematics-related beliefs. 


\section{Methods}

The design of this study is qualitative research. The population of this research was 12 Indonesian lower secondary mathematics teachers from Surabaya and Sidoarjo. Those teachers were selected from the result of interview using a belief-related task to discuss what best instructional sequences should be implemented into a mathematical problem within classroom activity. And then, we selected Bian (male) and Adi (male) of participants since they seemed to portray their beliefs in an intrumental view.

Data were conducted by using individual interviews for two participants about their beliefs and knowledge about mathematical problem solving. The beliefs include three components, i.e. nature of mathematics, how to teach mathematics, and how students learn mathematics; while the knowledge includes problem solving content knowledge and pedagogical problem solving knowledge. To collect the data of teachers' belief we used a set of task-based interviews whose cases are extracted from description of instrumentalist beliefs presented in table 2 . Such tasks were arranged in the form of incomplete statements. We also provided three options for each incomplele statement illustrating description of each of beliefs. Each of the teachers was asked to choose one of the options which mostly represent his view and explain why he chose that option. Then, we also asked them to compare his argumentation with the other two remaining options.

To analyze teachers' practice, we were guided by framework we developed according to Polya's model of solving problem. We focused on the significant feature of how each of the teachers guided students in each of problem solving stages and if possible, looked into the difference and similarity among those teachers' pattern on the teaching practice.

\section{Results}

\subsection{Bian's Beliefs, Knowledge and Practice about Mathematical Problem Solving}

Bian 's view of nature of mathematics was mostly aligned with Instrumentalist, especially when he argued about what one should take away from mathematics and when he defined mathematics. He preferred to have proficiency in calculating as well as applying formulae and procedures because he said,"I think one needs to master the concepts to understand how to apply mathematical formula,...most of mathematics teaches us to calculate." This is in line with his options emphasizing that mathematics is a discipline discussing calculation, numbers, and formulae. He asserted his belief by arguing that strategies of solving problem will only be succesful if one knows similar problem they ever encountered.
However, when he was asked to link between real life problem and mathematics, he preferted to choose the statement that there are parts of the topics in mathematics used to solve real life problems and there are also parts of mathematics used to develop the topics of mathematics itself. In this case, however, it indicates his platonist view.

His instrumentalist view also appeared on most cases examined in group of 'teaching mathematics' statements, i.e. on viewing the role of teacher, the precise time on teaching contextual problem, ways to minimize students' misundertanding, and strategy of motivating students on particular topic. In viewing the latter two cases, for example, he told, " I choose to clarify their misunderstanding by giving a more detaied explanation particularly on the parts in which they find difficulties instead of letting them discuss because if I pose questions, they are often confused, no feed back.", and "to motivate students to learn something difficult to understand its application, I used to explain more clearly on the prerequisite knowledge for learning, in this case, central and circular angle." Ultimately, when he responded on the best way to teach mathematics, he viewed, "teaching math should start with giving concepts, exercise from easy to difficult".

In responding how students should learn mathematics, Bian's views also indicate on Instrumentalist. He argued that students need to practice many times to master concepts or procedures inherent in the problem, need to only focus on particular strategy which can be applied to many types of problem by repeating such strategy many times rather than learning various strategies that may not be applicable in the task students are solving, and must not use calculator whatever the reason is. Nevertheless, in viewing formula, he told, " they [students] may use formula given in the book or learn how such formula is constructed, but more importantly, they should develop their own 'formula' to solve any problem.". He seemed to have problem solving view in this case.

Regarding knowledge, Bian seemed to have partial understanding, primarily on meaning of mathematical problem, types of problem, problem solving process and strategies. When asked about whether particular mathematical questions are problem or not for students, he knows that a problem should be challenging, interesting, and have no immediate solution, but he asserted that a question which demands insufficient prerequisite knowledge is a problem. He said, "question 'find the area bounded by curves $y=x^{2}+1, x=-4, x=5$, and $\mathrm{x}$-axis' is a problem for my students because they require certain formula which is not learned yet'. Besides, Bian was seemeingly unable to select appropriate problem for her lesson as indicated when he incorrectly explained about for what purpose a particular problem is designed. He said, "this problem [a problem about finding concept of circle area) is designed for mastering sudents' skill in applying formula of circle area. I don't think it works on my sudents if I give it in early learnng of circle area". Data also indicate 
that Bian incompletely mentioned problem solving process. He noticed, "when solving problem, I need to firstly understand, then choose suitable strategies, and apply such strategies". No indication appeared that solving problem needs also process of looking back as suggested by scholars. Explaining about implementation of problem solving process within classroom, Bian was not able to explain an ideal process of guiding students to solve problem as indicated by his statement, “...students are asked to read the problem and listen to what I explained to understand the problem...let them choose methods and apply such method...'.Accordingly, his guidance is rather teacher-centered in the beginning of solving problem.

Bian selected scales problem and pattern numbers in a table for his lesson. Generally, directive teaching was mostly appeared on his lesson, from understanding problem stage until looking back stage. When helping students understand the problem, Bian did not engage students in figuring out the situation of the problem and connecting the problem with students' prior mathematical knowledge. In case of scales problem, he jumped the step by directly telling students what the problem asked about and asking them to find the number of balls, cylinder, and cubes for balancing the scales. Such directive teaching continued primarily until the stage of determining a plan for finding solution. Despite of the fact that he asked students to use their own strategy, it was proven that he offered explicitly an example of an idea to find the solution. The following transcript illustrates this finding.

Bian said that" It's better for you to use your way to solve. But, this is only one alternative. The key is that you need to pay attention to the number of balls that make the scale balance for one cylinder as you see in scales A. Now, compare how many balls you need to substitute the number of cylinders in scales B, and so on."

Once the students carried the strategy offered by Bian, the lesson continued with discussing the solution from students' work. Unlike in the early stages of helping his students, Bian gave an opportunity for students to compare their solution within a group presentation. However, when guiding students to present their work, he only asked them to explain their work to other students, instead of asking to give an opportunity for other students to give feedback about the plausibility of the solution or possible other solutions offered by them. Rather, he decided by himself whether the answer presented by the presenting group was correct or incorrect.

Within the stage of looking back, Bian also did not carry out most of activities such as asking students' difficulties related to the strategies they selected, asking student to think of more likely effective strategies and all possible solution, or even extending the problem in a more complex situation and, moreover, discussing the changes in solution or strategies when the situation of initial problem is manipulated. Thus, Bian's stage of guiding students in looking back was insufficient.

\subsection{Adi's Beliefs, Knowledge and Practice about Mathematical Problem Solving}

Adi expressed a deep belief that his nature of mathematics regards with Instrumentalist view as indicated by his responses in data. It is seen from the answers beliefs about what should be controlled by a person after studying mathematics and at solving mathematical problems. He prefers to have skills in numeracy and apply formulas and procedures, because he said "smoothly counting will be able to help resolve the problems of daily life". In addition, he said that mathematics is the science of numbers, calculations and formulas related to the problem of life. It is believed that the problem-solving strategy will only be successful if the mathematical concepts and procedures used by the teacher are correct. However, when he was asked to look for relationships mathematical topics with the problems of daily life, he believes that there are parts of the topics in mathematics used to solve real life problems and there are also parts of mathematics used to develop the topics of mathematics itself.

In teaching mathematics, Adi also showed instrumentalist. This looks at how best to help students in solving problems, the precise time on teaching contextual problem, ways to minimize students' misunderstanding, and strategy of motivating students on a particular topic. He prefers to introduce solution of systems of linear equations of two variables, namely the elimination and substitution methods to be applied in resolving the problem, because he "changed the problem into equation, and then applied to the elimination or substitution method". He also believes that the time that is right to teach math problems is at the beginning of the introduction of new material, because of that the students are interested and challenged. In other cases, it appears that he prefers to straighten out misunderstandings providing students with a more detailed explanation, especially on the misunderstood. He also motivates students to learn mathematics by using a good strategy and then giving awards to these students. Then, he gives an opinion on the best way of teaching mathematics, namely discussion of the issues, the problems continued discussion of the concepts, examples of problem and its applications in everyday life.

Adi showed instrumentalist when viewed from how students learn mathematics. He said that students need to practice many times to understand the first concept, si needing to focus on one strategy that is considered most effective in solving various types of problems. He was convinced that the calculator does not have to be used in learning mathematics because it will make them learn the basic concepts of mathematics. However, in looking at the formula, he tried to understand the process of derivation in the book so it could find if one day forgetting that formula. In this case, he looks to have a platonic view.

Regarding Adi's problem solving knowledge, he had a partial understanding, especially on the meaning of mathematical problems, types of problems, problem 
solving and problem-solving strategies in teaching. He said that there are some mathematic tasks that are the problem, and there is also no problem for students, depending on the material provided. Mathematic task for students is said to be a problem when the problem is about the story, and combined concept. In addition, he also confirmed that a task is problem, if this task is challenging, interesting, cannot be done immediately, and he has not prerequisite for use in the search for a solution to a problem. This is evident in D03 task about area bounded by the line $y=x^{2}+$ $1, x=-4, x=5$, and the $x$-axis. If viewed from this type of problem, he differentiates the types of problems into three, namely, description of questions, multiple choice questions, and about mapping. Moreover, Adi can choose the problem based on aim of problem created for students, where it can build circles concept and implement the solution of system of linear equations of two variables. Based on the data, when he asked "why it is important to apply problem-solving in mathematics?", he answered "at least apply the concept, trained to think that is useful in daily life". Besides, the steps of problem solving, she began to formulate things that are known, determine who asked, choose a strategy, implement the strategy, and conclude . But in implementation, he was heavily involved in guiding students to solve a problem.

Adi chose about scales, football and concentric temple problems in learning in class. At this stage of understanding, Adi involved students in understanding the problem situation by asking the meaning of the word "refurbished". He explained the purpose of each question without asking other students to explain the concept of the question. In the next stage of devicing a plan, he asked the students to make connections between pictures and patterns of numbers tha are possible. He needsmore time to make the students understand the problem in question. This is because the student worksheet provided directly given to students at the beginning of learning, not discussed at the beginning of learning. In carrying out the plan, he did not make sure every group that the group answers are correct or incorrect. In the last stage that is looking back, she asks students to apply their answers on the board, and then check again the strategy of each group as the results show many differences. But at this stage, he does not generalize the process and solution obtained in the form of general and does not conclude the students' answers at the end of learning.

\section{Discussion and Conclusions}

From the results above, we can see some similarities between Bian and Adi, mainly there is consistency between beliefs, knowledge and their teaching practices which are both included instrumentalist. They prefer to have skills in numeracy and apply formulas and procedures after learning of mathematics, motivate students by rewarding, choosing the most effective strategy which can be used for different types of problems. Moreover, they performed similar ways in their teaching practice, which is directive particularly when guiding their students in early stages of solving mathematical problems, i.e. understanding problem and devising plan. Comparing those two teachers, we found that, despite the fact that both the teachers espoused their beliefs in different ways regarding the extend to which associate factors such as immediate classroom situation, teacher education program, and social teaching norms influence their beliefs.

Based on immediate classroom situation, in Bian class, there are only a few students who were able to work on a given problem, and students consider the question is very difficult. This is evident from the behavior of students who crowded when working on the problems in the classroom. However, look different in Adi's class. Most students can work on the problems and the student's behavior was not crowded in working a problem so it does not interfere with the learning process. While in the teacher education program, they look different. Adi already seems ripe in the experience of teaching, but Bian is still less visible in the experience of teaching. This happens, because at the time of interview Adi said in a statement that he often followed the teacher training program, in contrast with the Bian becoming a teacher after graduating from undergraduate. While on teaching social norms, Adi already is implementing the curriculum 2013, so that the learning in class is already using the book of curriculum 2013. As a result, students do not feel difficulty in doing some of the questions given by him, because it is already accustomed to solving on the problems standard test given in the book of curriculum 2013. But it is different in class Bian, he still applies curriculum 2006, so that students are still not accustomed to working on the problems standard test given by him in the class. This is in line with research Raymond (1997) showing that there are major causes of inconsistencies by the teacher in the classroom that is an element in the situation immediately and norms of social teaching.

This study result highlights the importance of analysing further relationship between beliefs, knowledge, and practice about mathematical problem as well as supporting the development of such three variables on secondary mathematics teachers.

\section{REFERENCES}

[1] Anderson, J., White, P. \& Sullivan, P. (2005). Using a schematic model to represent influences on, and relationships between, teachers' problem solving beliefs and practices, Mathematics education research journal, 17(2), 9-38.

[2] Ball, D. L. (1990). Breaking with experience in learning to 
teach mathematics: The role of a pre-service methods course. For the Learning of Mathematics, 10(2), 10-16.

[3] Beswick, K. (2005). The belief/practice connection in broadly defined contexts. Mathematics Education Research Journal, 17(2), 39-68.

[4] Beswick, K. (2007). Teachers' beliefs that matter in secondary mathematics classrooms. Educational studies in mathematics, 65(1), 95-120

[5] Bray, W. S. (2011). A collective case study of the influence of teachers' beliefs and knowledge on error-handling practices during class discussion of mathematics. Journal for Research in Mathematics Education, 42(1), 2-38.

[6] Chapman, O. (2015). Mathematics teachers' knowledge for teaching problem solving. Lumat ,3, 19-36

[7] Clark, C. M., \& Peterson, P. L. (1986). Teachers' thought processes. In M. Wittrock (Ed.), Handbook of research in teaching (3rd ed.) (pp. 255 296). New York: MacMillan.

[8] Cobb, P., Wood, T., \& Yackel, E. (1990). Classrooms as learning environments for teachers and researchers. In R.B. Davis (Ed.), Constructivist views on the teaching and learning of mathematics (pp:125-146). Reston, VA: National Council of Teachers of Mathematics.

[9] Ekawati, R., Kohar, A. W., \& Hartono, S. (2017). Experts' notion and students' responses on context-based mathematics problem. Journal of Engineering Science and Technology (JESTEC), 53-64.

[10] Ernest, P. (1989). The impact of beliefs on the teaching of mathematics. In P. Ernest (Ed.), Mathematics teaching: The state of the art (pp. 249-253). New York: Falmer.

[11] Fang, Z. (1996). A review of research on teacher beliefs and practices. Educational Research, 38(1), 47-65.

[12] Franke, M. L., Kazemi, E., \& Battey, D. (2007). Mathematics teaching and classroom practice. In $\mathrm{F}$. $\mathrm{K}$. Lester Jr. (Ed.), Second handbook of research on mathematics teaching and learning (pp. 225-256). Charlotte, NC: Information Age.

[13] Grigutsch, S., Ratz, U. \& Törner, G. (1998). Einstellungen gegenüber Mathematik bei Mathematiklehrern [Mathematics teachers' attitudes toward mathematics]. Journal für Mathematikdidaktik, 19, 3-45.

[14] Kagan, D. M. (1992). Implications of research on teacher belief. Educational Psychologist, 27, 65-90.

[15] Loewenberg Ball, D., Thames, M. H., \& Phelps, G. (2008). Content knowledge for teaching: What makes it special? Journal of teacher education, 59(5), 389-407.

[16] Ontario Ministry of Education. (2008). A Guide to Effective Instruction in Mathematics, Kindergarten to Grade 6 Volume Two. Toronto: Author

[17] Peressini, D., Borko, H., Romagnano, L., Knuth, E., \& Willis, C. (2004). A conceptual framework for learning to teach secondary mathematics: A situative perspective. Educational Studies in Mathematics, 56(1), 67-96.

[18] Raymond, A. M. (1997). Inconsistency between a beginning elementary school teacher's mathematics beliefs and teaching practice. Journal for research in mathematics education, 550-576.

[19] Siswono, T. Y., Kohar, A. W., Savitri, D., \& Hartono, S (2017). Context-based problems and how engineering students view and learn mathematics. World Transactions on Engineering and Technology Education, 15(4), 355-360.

[20] Siswono, T. Y. E., Kohar, A. W., \& Hartono, S. (2017, February). Secondary Teachers' Mathematics-related Beliefs and Knowledge about Mathematical Problem-solving. In Journal of Physics: Conference Series (Vol. 812, No. 1, p. 012046). IOP Publishing.

[21] Siswono, T. Y. E., Kohar, A. W., Kurniasari, I., \& Astuti, Y. P. (2016, February). An Investigation of Secondary Teachers' Understanding and Belief on Mathematical Problem Solving. Journal of Physics: Conference Series, (693)1, 12015-12033.

[22] Shulman, L. (1987). Knowledge and teaching: Foundations of the new reform. Harvard educational review, 57(1), 1-23.

[23] Swan, M. (2007). The impact of task-based professional development on teachers' practices and beliefs: A design research study. Journal of Mathematics Teacher Education, 10(4-6), 217-237.

[24] Thompson, A. G. (1992). Teachers' beliefs and conceptions: A synthesis of the research. In D. A. Grouws (Ed.), Handbook of research on mathematics teaching and learning (pp. 127-146). New York: Macmillan.

[25] Wilson, S. M., Shulman, L. S., \& Richert, A. E. (1987). 150 different ways of knowing: Representations of knowledge in teachinteaching. In J. Calderhead (Ed.), Exploring teachers' thinking (pp. 104-124). Sussex: Holt, Rinehart \& Winston. 